МАСЛОВА Н. Г.,

кандидат юридичних наук, докторант

(Харківський національний університет

внутрішніх справ)

УДК 343.93

DOI https://doi.org/10.32842/2078-3736-2019-6-1-10

\title{
ДІЯЛЬНІСТЬ ПРАВООХОРОННИХ ОРГАНІВ УКРАЇНИ У СФЕРІ ЗАПОБІГАННЯ КРИМІНАЛЬНОМУ РАДИКАЛІЗМУ
}

У статті досліджено роботу правоохоронних органів України крізь призму їх діяльності як суб'єктів протидії кримінальному радикалізму. Діяльність зазначених органів розглянуто через здійснення ними спеціально-кримінологічного запобігання злочинам радикального спрямування. Визначено основні заходи протидії кримінальному радикалізму залежно від стадії виявлення правоохоронними органами злочинної діяльності, починаючи з виявлення причин та умов, що детермінують злочинні прояви кримінального радикалізму, до припинення злочинної діяльності незаконних збройних або військових формувань та окремих осіб. Запропоновано такі основні напрями припинення зазначених злочинних проявів як складника спеціально-кримінологічного запобігання: 1) правове забезпечення припинення злочинів, групових порушень громадського порядку та громадської безпеки. Назріла необхідність прийняття низки законодавчих актів, зокрема, законів «Про опозицію», «Про порядок проведення масових заходів», «Про дії органів внутрішніх справ при виникненні групових порушень громадського порядку та громадської безпеки», які визначили б повноваження державних органів під час планування та здійснення заходів щодо керівництва всіма силами і засобами на випадок ускладнення оперативної обстановки; 2) нормативне забезпечення тактики втручання у кризові ситуації, тобто унормування низки організаційно-управлінських принципів, форм, методів такого втручання (наприклад, створення спеціальної системи управління силами і засобами під час ліквідації групових порушень громадського порядку і масового безладу, опанування нових тактичних схем маневру ресурсами та впливу на натовп з агресивним настроєм, сценарії узгодженості спільних дій підрозділів правоохоронних органів тощо); 3) наукове забезпечення тактичних і психологічних прийомів щодо припинення злочинів, у тому числі масових безпорядків, погромів, радикальних, екстремістських та терористичних дій; 4) забезпечення комплексного характеру дій з припинення злочинів, що передбачає обмін інформацією із взаємодіючими органами під час проведення спеціальних операцій.

Ключові слова: протидія злочинності, кримінальний радикалізм, спеціальнокримінологічне запобігання, правоохоронні органи.

The article explores the work of law enforcement agencies of Ukraine through the prism of their activities as subjects of counteraction to criminal radicalism. The activities of these agencies were considered through the implementation of their special criminological prevention of radical crimes. The basic measures of counteraction to criminal radicalism, depending on the stage of detection by law enforcement agency of criminal activity, from the identification of the causes and conditions that determine the criminal manifestations of criminal radicalism to the termination of criminal activity of illegal armed or military formations and individuals, are determined.

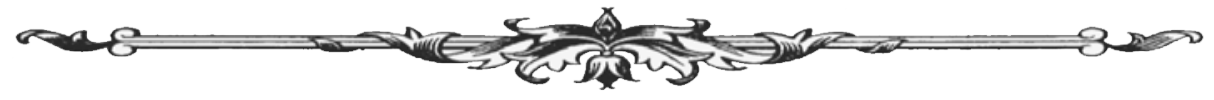


It is proposed to distinguish several groups of special measures against criminal radicalism, namely:

1) at the stage of detection, elimination and neutralization of the causes and conditions of negative phenomena that have arisen or may occur and determine criminal manifestations of radical direction; 2) in the detection of illegal armed and military formations or of specific persons who carry out criminal intentions and may, due to their behavior or perceptions of a criminal lifestyle, engage in or be involved in terrorist activities; 3 ) during the termination of a criminal act during the preparation or attempted phase.

The main activities of theory and practice termination of criminal offenses should be considered: 1) legal support for the termination of crimes, group violations of public order and public security; 2) regulatory support for tactics of intervention in crisis situations, that is, solving a number of organizational and management principles, forms, methods of such intervention; 3) scientific support tactical and psychological techniques to curb crimes, including mass disturbances, riots, radical, extremist and terrorist activities; 4) complexity of practical actions to stop crimes, which involves the exchange of information with the cooperating agencies during special operations.

Key words: counteraction to crime, criminal radicalism, special criminological prevention, law enforcement.

Вступ. Посилення радикальних настроїв у суспільстві, продовження антитерористичної операції на сході країни, подальше економічне розшарування населення породжує загострення політичної боротьби між політичними партіями, що викликає використання радикальних засобів і знарядь, в тому числі з потенційною загрозою реалізації найбільш негативних сценаріїв у суспільстві. Наприклад, політичні рішення влади щодо розведення сил у с. Золотому призвели до конфлікту з окремими політичними партіями та громадськими організаціями, зокрема 3 «Національними дружинами», та потенційно можуть викликати збройну конфронтацію, порушення громадської безпеки та порядку окремими представниками таких сил [1]. У цьому контексті особливої уваги вимагає посилення ролі правоохоронних органів з питань спеціально-кримінологічного запобігання кримінальному радикалізму.

Аналіз останніх досліджень. Різноманітним аспектам протидії злочинності присвячено праці Г.А. Аванесова, А.І. Алексєєва, Ю.М. Антоняна, О.М. Бандурки, В.М. Бесчастного, О.В. Бокова, С.Є. Віцина, В.В. Голіни, Л.М. Давиденка, І.М. Даньшина, О.М. Джужі, Е.О. Дідоренка, А.І. Долгової, А.Е. Жалинського, А.П. Закалюка, А.Ф. Зелінського, О.М. Ігнатова, І.І. Карпеця, О.Г. Кальмана, Я.Ю. Кондратьєва, В.М. Кудрявцева, Н.Ф. Кузнєцової, О.М. Литвака, О.М. Литвинова, Ф.А. Лопушанського, В.В. Лунєєва, М.І. Мельника, С.Г. Міщенка, П.П. Михайленка, О.Б. Сахарова, В.М. Соміна, О.О. Степанченка, Н.О. Ярмиша та інших науковців.

Постановка завдання. Метою статті є визначення ролі та вдосконалення ефективності діяльності правоохоронних органів у сфері спеціально-кримінологічного запобігання кримінальному радикалізму.

Результати дослідження. Спеціально-кримінологічне запобігання будь-яким злочинам складається із трьох напрямів діяльності: 1) кримінологічної профілактики; 2) відвернення злочинів; 3 ) припинення злочинів. Зазначену діяльність, відповідно, розподіляють на три етапи: 1) до формування мотиву злочинного прояву та мотиву його вчинити; 2) після його сформованості, але до початку реалізації; 3) після початку реалізації наміру через здійснення конкретних злочинних дій [2, с. 23].

Таке розуміння поняття спеціально-кримінологічного запобігання надає можливість сформулювати основні завдання такого запобігання кримінальному радикалізму: виявлення, усунення та нейтралізація причин і умов негативних явищ, які виникли чи можуть виник-

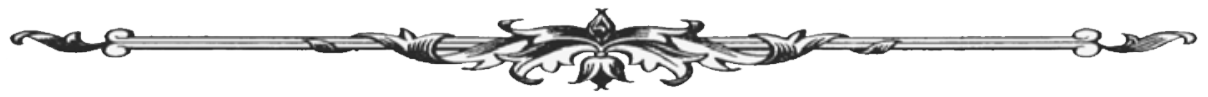


нути й детермінувати злочинну радикальну діяльність або їі окремі прояви; виявлення груп чи конкретних осіб, які виношують злочинні наміри та можуть унаслідок своєї поведінки або сприйняття злочинного способу життя вдатися чи бути втягнутими до такої діяльності, здійснення на них профілактичного впливу з урахуванням їхніх особистісних властивостей; припинення розпочатої злочинної поведінки на стадії підготовки або замаху [3, с. 149].

На першому етапі сфера застосування запобігання $є$ досить широкою, оскільки охоплює джерела негативних процесів, що детермінують формування антисуспільної спрямованості особистості, а також інших детермінантів формування цієї особистості. Запобігання на цій стадії відрізняється завчасним виявленням і профілактичним впливом на ті процеси та явища, які потенційно можуть відігравати роль причин і умов учинення конкретного злочину до формування його мотиву. На цьому етапі виховні, соціально-психологічні, педагогічні, медичні, індивідуально-побутові заходи переважають над кримінологічними. Зокрема, медико-реабілітаційні заходи, пов'язані з психологічною допомогою, входять до переліку соціальних послуг, які Україна гарантує ветеранам та учасникам бойових дій на Донбасі. Так, основним завданням Закону України «Про статус ветеранів війни, гарантії їх соціального захисту» $€$ :

- створення належних умов для підтримання здоров'я та активного довголіття;

- організація соціального та інших видів обслуговування, зміцнення матеріально-технічної бази створених для цієї мети закладів і служб та підготовка відповідних спеціалістів;

- виконання цільових програм соціального і правового захисту ветеранів війни;

- надання пільг, переваг та соціальних гарантій у процесі трудової діяльності відповідно до професійної підготовки і з урахуванням стану здоров'я.

На наступному етапі формування мотиву злочину й наміру його вчинити конкретною метою $є$ відвернення можливості реалізації злочинного наміру. Відвернення злочинів - це активна специфічна запобіжна діяльність, спрямована на усунення імовірності вчинення задуманих злочинів шляхом розробки і здійснення цілеспрямованих заходів. Не кожний злочинний намір обов'язково реалізується. Особа може відмовитися від його вчинення як самостійно, так і під впливом різних об'єктивних обставин, а тим більше у результаті цілеспрямованої професійної діяльності спеціалізованих органів. Саме завдяки такій діяльності в осіб виникають контрмотиви до вчинення злочинів. Своєчасне вжиття заходів, розробка і здійснення яких сприяє появі сумніву і відмови від скоєння злочину, дуже часто є тією перешкодою, що стає на заваді реалізації злочинного наміру. Значна частина таких заходів пов'язана з проведенням оперативно-розшукових дій відповідно до Закону України «Про оперативно-розшукову діяльність». Заходи запобігання злочинній мотивації ділять на дві великі групи: 1) заходи переоріснтації антисуспільної настанови; 2) активні контрзаходи. Заходи першої з названих груп включають таке: а) спеціальні економічні та соціально-психологічні програми, які розраховані на те, щоб людина в суспільстві отримувала більш-менш повне задоволення своїх потреб і відмовлялась від злочинних намірів; б) заходи, спрямовані на формування в громадян антикримінальної культури; в) кримінологічна поінформованість населення для його більш тісного співробітництва 3 правоохоронними органами; г) організаційно-правові заходи, які підвищують у людей почуття відповідальності й виробляють у них уявлення про допустимі засоби досягнення своїх потреб. Заходи другої з названих груп (активні контрзаходи) - це заходи переконання, різних форм примусу, застереження й допомоги особам, звільненим із місць позбавлення волі. Оперативно-розшукові заходи досить часто поєднуються з індивідуально-психологічними.

На стадії припинення злочинної діяльності переважають криміналістичні та процесуальні заходи. Це дає підставу для окремого відображення в єдиній статистиці показників щодо профілактики, відвернення і припинення злочинів радикального спрямування. В.В. Голіна, досліджуючи питання припинення злочинних посягань й виходячи з сучасних умов поширення злочинності політичного, етнічного, конфесійного, радикального, екстремістського, національного спрямування, що має масовий, відкрито агресивний, нерідко

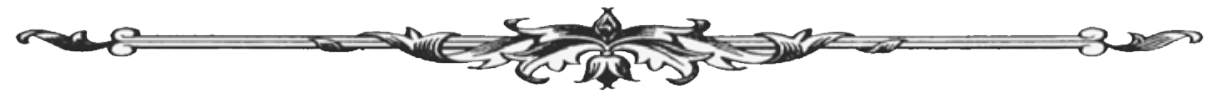


озброєний характер, робить висновок про необхідність вироблення нових сценаріїв зупинки таких керованих, організованих злочинних ексцесів, коли задіяння правоохоронних органів неефективне, розробка теоретичних, правових і практичних заходів припинення цих злочинів не дає відчутного результату [2, с. 36].

Наведене свідчить про принципову відмінність етапів спеціально-кримінологічних запобігань кримінальному радикалізму з огляду на їхню мету й спрямування. Їхня специфіка полягає в тому, що значна їх частина пов'язана з державним примусом, тобто з обмеженням конституційних прав і свобод людини. Ця примусова частина потребує окремої законодавчої регламентації. Звідси випливає, що запобігання злочинності, у тому числі кримінально радикального спрямування, крім принципів соціального управління, має відповідати правовим принципам, найважливішим із яких є принцип законності.

Пропонується вирізнити декілька груп спеціальних заходів протидії кримінальному радикалізму, а саме:

1) на етапі виявлення, усунення й нейтралізації причин та умов негативних явищ, які виникли чи можуть виникнути й детермінувати злочинні прояви радикального спрямування; 2) під час виявлення незаконних збройних та військових формувань чи конкретних осіб, які виношують злочинні наміри та можуть унаслідок своєї поведінки або сприйняття злочинного способу життя вдатися чи бути втягнутими до терористичної діяльності; 3) під час припинення розпочатої злочинної поведінки на стадії готування або замаху. Інколи ці заходи можуть здійснюватися одночасно.

На першому етапі важливим складником роботи є збір та аналіз тенденцій поширення кримінального радикалізму в Україні й за їі межами. На підставі системного аналізу інформації про тенденції поширення такої діяльності в Україні та за її межами, багатовимірного комплексного оцінювання причин і умов, що впливають на виникнення й поширення злочинних дій радикального спрямування, до органів державної влади вносяться в установленому порядку пропозиції для вжиття відповідних заходів, прийняття відповідних управлінських рішень.

Основними напрямами запобіжної роботи на етапі виявлення, усунення й нейтралізації причин та умов негативних явищ, які виникли чи можуть виникнути й детермінувати кримінальний радикалізм, $є$ такі:

1) впровадження ідеї кримінологічної експертизи окремих законопроектів, що надасть можливість корекції змісту проектів щодо усунення сумнівних або суперечливих норм чи взагалі відмови від певних законопроектів, які можуть сприяти посиленню конфліктів у суспільстві та створенню додаткових умов для «прогресу» злочинності; 2) контроль за обігом та своєчасне запобігання незаконному розповсюдженню вогнепальної, холодної зброї та вибухових речовин, в тому числі з залученням правоохоронних служб іноземних країн; 3) організація заходів соціальної та психологічної реабілітації учасників бойових дій на Сході країни; 4) залучення приватних підприємств до профілактичної діяльності запобігання кримінально радикальним проявам у суспільстві; 5) періодичне проведення перевірок та експериментів, спрямованих на виявлення передумов учинення радикальних, екстремістських та терористичних дій на потенційно уразливих об’єктах (підприємствах, публічних місцях), підвищення рівня безпеки зазначених об'єктів; 6) організація роботи, спрямованої на запобігання можливим радикальним проявам під час підготовки та проведення загальнодержавних і місцевих заходів із масовим перебуванням людей, забезпечення належного рівня безпеки та контролю в цих місцях; 7) проведення на об’єктах можливих злочинних посягань командно-штабних, тактико-спеціальних навчань і тренувань із залученням сил і засобів суб'єктів, які безпосередньо здійснюють боротьбу з зазначеними проявами антигромадської поведінки; 8) розроблення й упровадження особливих правил безпеки, зокрема стандартів, кодексів усталеної практики (настанов, правил, зводів правил), технічних умов захищеності об'єктів від можливих злочинних посягань радикального, екстремістського, терористичного спрямування.

Важливою є правороз'яснювальна робота в інтересах запобігання можливому вчиненню правопорушень, яка полягає в проведенні комплексу заходів правового й вихов-

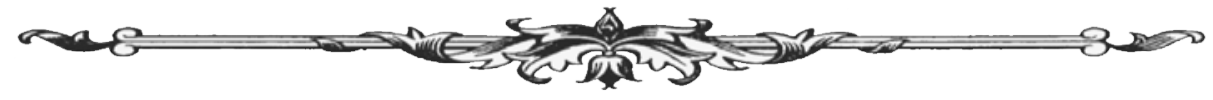


ного характеру, що постійно здійснюються уповноваженими органами шляхом доведення до населення через засоби масової інформації, мережу Інтернет інформації про досягнуті результати боротьби з протиправним посяганням з боку кримінально налаштованих організацій, організованих злочинних угруповань, доведення змісту положень чинного законодавства щодо прав і обов'язків суб'єктів боротьби з кримінальним радикалізмом, відповідальності за вказану діяльність, а також видання літератури з правової тематики.

Важливим запобіжним заходом на етапі виявлення, усунення, нейтралізації причин та умов негативних явищ, що виникли чи можуть виникнути й детермінувати кримінально радикальну діяльність, є направлення письмових повідомлень на адресу державних органів, органів місцевого самоврядування, підприємств, установ і організацій стосовно конкретних фактів, причин і умов, що можуть сприяти вчиненню злочинів радикального спрямування, з пропозиціями щодо їх усунення.

Підставами для таких профілактичних заходів $є$ наявність достатньої інформації, яка свідчить про наміри проведення окремими особами чи організаціями такої діяльності або виникнення негативного процесу, неконтрольований розвиток якого може вплинути на стан об’єктів можливих радикальних посягань чи спричинити вчинення такого посягання.

На етапі виявлення незаконних збройних або військових формувань чи окремих осіб основними напрямами запобіжної роботи варто визнати такі заходи: 1) обмін інформацією щодо: а) злочинної діяльності осіб, причетних до кримінального радикалізму, в тому числі міжнародного фінансування, підтримки чи вчинення злочинів зазначеного спрямування; б) заволодіння або виникнення загрози заволодіння зазначеними групами зброєю, вибуховими речовинами, іншими засобами масового ураження; 2) припинення спроб іноземців, щодо яких є дані про їх причетність до міжнародних радикальних, екстремістських, терористичних груп чи організацій, здійснювати транзитний проїзд через територію України.

На цьому етапі потрібно вжити заходів запобігання діям або пересуванню радикалів, незаконних військових або збройних формувань, а також осіб, які підозрюються в фінансуванні та підтримці зазначених груп.

Реалізація заходів оперативно-розшукової діяльності - один із найголовніших напрямів спеціального запобігання кримінальному радикалізму. Надані чинним законодавством засоби оперативно-розшукової діяльності дають досить широкі можливості для контролю криміногенної обстановки, своєчасного виявлення загроз і їх чинників, а звідси - активно протидіяти вчиненню конкретних злочинів або розширенню соціальної бази для радикалізму. Провідна роль у виявленні злочинної діяльності радикального спрямування належить оперативним підрозділам Національної поліції та Служби безпеки України, які в процесі виконання службових обов'язків виявляють і аналізують оперативну інформацію, що може свідчити про злочинну діяльність окремих осіб чи організацій. Для цього ці підрозділи застосовують багато методів і способів оперативно-розшукової діяльності.

На етапі припинення розпочатої злочинної поведінки, на стадії готування або замаху великого значення набувають оперативно-розшукові та профілактичні заходи, в результаті яких відбувається запобігання розпочатій злочинній діяльності. Припинення злочинів розглядається як суто професійна оперативно-розшукова діяльність спеціалізованих підрозділів, передусім правоохоронних органів [2, с. 35].

До суб'єктів протидії кримінального радикалізму, що здійснюють спеціально-кримінологічне запобігання, слід віднести: 1) суб'єкти, що безпосередньо здійснюють боротьбу 3 кримінальним радикалізмом; 2) суб'єкти, що можуть у разі необхідності залучатися до боротьби з кримінальним радикалізмом. Такий поділ В.В. Майоров називає дворівневою типізацією суб' єктів, які здійснюють боротьбу зі злочинністю [4, с. 7].

Профілактика терористичних проявів вимагає від спеціальних служб постійної роботи, спостереження за оперативною обстановкою в радикальному середовищі й ужиття заходів для унеможливлення розширення цього середовища за рахунок осіб, які підтримують радикальну ідеологію. Розв'язання цих завдань можливе лише за умови єдності зусиль суб’єктів боротьби з кримінальним радикалізмом, їхньої скоординованої взаємодії.

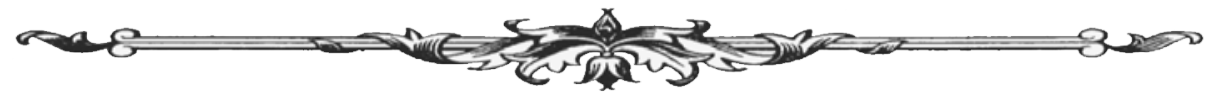


Багатоаспектність цієї діяльності потребує зосередження уваги на узгодженні та об’єднанні зусиль правоохоронних органів із забезпечення кримінального переслідування причетних до радикальної злочинної діяльності осіб, починаючи з моменту їх виявлення і до припинення злочинної діяльності.

Висновки. Погоджуючись 3 провідними кримінологами щодо необхідності пошуку нових підходів у протидії сучасній злочинності [2, с. 38], основними заходами теорії і практики припинення злочинних проявів як складника спеціально-кримінологічного запобігання злочинності слід вважати:

- правове забезпечення припинення злочинів, групових порушень громадського порядку та громадської безпеки. В контексті нашого дослідження назріла необхідність прийняття низки законодавчих актів: «Про опозицію», «Про порядок проведення масових заходів», «Про дії органів внутрішніх справ при виникненні групових порушень громадського порядку та громадської безпеки», які визначили б повноваження державних органів під час планування та здійснення заходів щодо керівництва всіма силами і засобами на випадок ускладнення оперативної обстановки;

- нормативне забезпечення тактики втручання у кризові ситуації, тобто вирішення низки організаційно-управлінських принципів, форм, методів такого втручання (наприклад, створення спеціальної системи управління силами і засобами під час ліквідації групових порушень громадського порядку і масового безладу, опанування нових тактичних схем маневру ресурсами та впливу на натовп з агресивним настроєм, сценарії узгодженості спільних дій підрозділів правоохоронних органів тощо);

- наукове забезпечення тактичних і психологічних прийомів щодо припинення злочинів, у тому числі масових безпорядків, погромів, радикальних, екстремістських та терористичних дій;

- комплексність практичних дій $з$ припинення злочинів, що передбачає обмін інформацією із взаємодіючими органами під час проведення спеціальних операцій.

Наприкінці зауважимо, що неприйняття державою необхідних заходів з припинення діяльності радикально налаштованих верств населення та доведення ситуації до озброєного політичного протистояння призводить до неконтрольованих та небезпечних процесів, які загрожують самому існуванню держави. Яскравим прикладом є події останніх десятиріч в Україні.

Список використаних джерел:

1. На Луганщині поліція з пострілами не пускала націоналістів до Золотого URL : https://www.umoloda.kiev.ua/number/0/2006/138339/.

2. Голіна В.В. Запобігання злочинності (теорія і практика) : навч. посіб. Харків : Нац. юрид. акад. України, 2011. 120 с.

3. Чорний О. Діяльність правоохоронних органів України у сфері запобігання терористичній діяльності. Visegrad journal on human rights. 2016. № 2(1). С. 148-151.

4. Майоров В.В. Адміністративно-правовий статус суб'єктів протидії тероризму в Україні : автореф. дис. ... канд. юрид. наук : 12.00.07. Київ, 2010. 22 с.

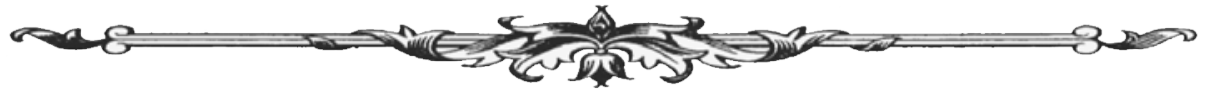

